\title{
Regulation of Appetite, Satiation, and Body Weight by Enteroendocrine Cells. Part 1: Characteristics of Enteroendocrine Cells and Their Capability of Weight Regulation
}

\author{
Carsten Posovszky ${ }^{a}$ Martin Wabitsch ${ }^{b}$ \\ a University Outpatient Clinic for Pediatric Gastroenterology, and b Division of Pediatric Endocrinology and Diabetes, \\ Department of Pediatrics and Adolescent Medicine, University Medical Center Ulm, Ulm, Germany
}

\section{Key Words}

Enteroendocrine cells · Satiation · Appetite · Obesity · Taste receptors · Macronutrients

\begin{abstract}
The gastrointestinal tract is the gateway for food in our body. Food ingestion and the ensuing digestive processes depend on the composition and amount of ingested nutrients. This complex process of nutrient digestion and absorption is effectively regulated by the enteroendocrine system. Enteroendocrine cells (EECs) reside scattered throughout the intestinal epithelium. They express nutrient receptors that face the lumen and secrete peptide hormones in response to food. Besides regulating digestion, gastrointestinal endocrine cells are involved in the regulation of appetite and satiety. The first part of this review describes the anatomical and biological characteristics of EECs and discusses the capability of their hormones to influence appetite, satiety, and body weight. In the second part, we then discuss the therapeutic potential of EECs in the treatment of obesity.
\end{abstract}

(c) 2014 S. Karger AG, Basel

\section{Introduction}

The gut plays a key role in the regulation of food intake in order to achieve efficient nutrient digestion and absorption. The perception of appetite and/or hunger leads us to eat, whereas gastric distension limits the extent of food intake and evokes the feeling of fullness, which is mainly mediated via vagal afferent stimulation. Interestingly, meals are typically stopped long before the gut capacity is reached [1]. Ingested food causes satiation not only by gastric distension but also by hormone secretion from enteroendocrine cells (EECs). The first studies of these secreted factors focused on the direct regulation of gastrointestinal (GI) function, such as secretin function on pancreatic secretion [2], cholecystokinin (CCK) on gallbladder contraction [3], and gastrin on gastric release [4]. The influence of CCK on appetite regulation was dis-

No grants or fellowships were received for the writing of this review; the authors have nothing to disclose.

\section{KARGER 125}

(c) 2014 S. Karger AG, Base

$1663-2818 / 14 / 0831-0001 \$ 39.50 / 0$

E-Mail karger@karger.com www.karger.com/hrp
Carsten Posovszky

Department of Pediatrics and Adolescent Medicine

University Medical Center Ulm, Eythstr. 24, DE-89075 Ulm (Germany)

E-Mail carsten.posovszky@ uniklinik-ulm.de 


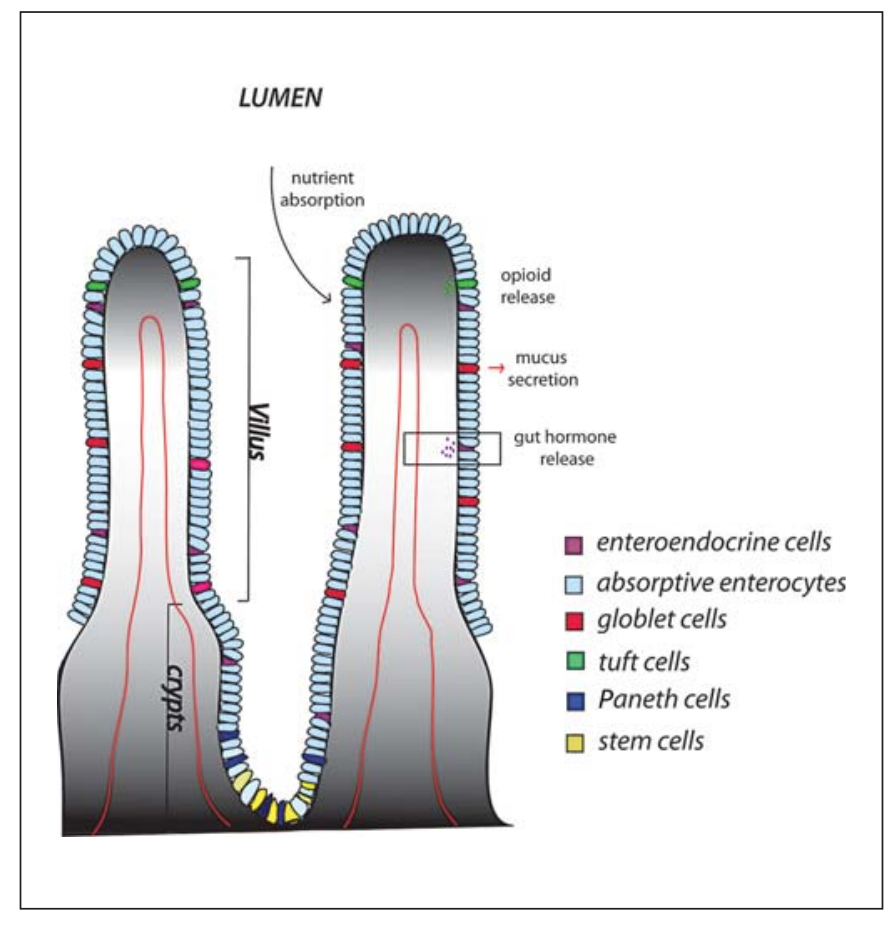

Fig. 1. Intestinal epithelial cell types. Intestinal epithelial cells develop from common stem cells in the crypt and differentiate into absorptive enterocytes, or secretory Paneth, goblet, tuft, and enteroendocrine cells. Upon differentiation, all but the Paneth cells migrate towards the villus tip. EECs migrate slowly in contrast to enterocytes or goblet cells. They are found scattered along the intestinal tract and release their granules upon luminal stimulation from their base. Adapted from Moran-Ramos et al. [88].

covered in 1973 [5] and prepared the ground for many other studies demonstrating that gut hormones signal the central nervous system to regulate meal initiation and termination on one hand and energy expenditure on the other [6]. The gut-brain axis is illustrated in the context of obesity treatment in part 2 of our review; here we focus on the capability of EECs and their hormones to influence body weight.

\section{EEC Development, Anatomy, and Biology}

The gut is one of the largest hormone-producing organs in the human body in terms of the number of endocrine cells present as well as numbers of hormones produced.

The enteroendocrine system of the GI tract produces more than 20 hormones, but represent only $\sim 1 \%$ of the intestinal epithelial cell population. EECs are scattered throughout the GI tract between absorptive enterocytes, opioid-releasing tuft cells, and secretory goblet and $\mathrm{Pa}$ neth cells (fig. 1) [7]. EECs are terminally differentiated cells that arise from pluripotent intestinal crypt stem cells (fig. 1) under the control of three basic helix loop helix transcription factors, Math1, neurogenin 3 (NGN3), and neurogenic differentiation 1 [8-10]; however, relatively little is known about the segregation into the different cell lineages.

There are at least 15 EEC subtypes and most of them display a characteristic distribution pattern within the GI tract as summarized in table 1. Upon activation they release the content of their basal storage organelles, which can stimulate afferent nerves or nearby cells in a paracrine fashion or enter the bloodstream as classical hormones (fig. 2) [11]. Initially, EECs were defined and named according to their morphology or the secreted peptide hormone, e.g. G cells secrete gastrin. It is nowadays well known that EECs can secrete more than one hormone, e.g. L cells produce glucagon-like peptide-1 (GLP-1), GLP-2, peptide YY (PYY), oxyntomodulin (OXM), and glicentin. Most EECs reach the lumen with their apical domain exhibiting microvilli and are called 'open type'. In contrast, 'closed-type' EECs are separated by epithelial tight junctions (e.g. histamine-producing ECL cells). Over the past few years it became evident that the 'opentype' EECs act as sensors for the composition of the intestinal luminal content and regulate the secretion of gut peptides accordingly. This mechanism was already known, having been published in 1902 by Bayliss and Starling [2]. They demonstrated that duodenal acidification induced secretion of pancreatic digestive fluid via the release of the gut hormone secretin $[2,12]$. In addition to a chemical trigger, EECs react on physical stimuli, e.g. distension of the gut, with serotonin (5-HT) secretion [13]. More recently, different nutrient receptors such as sodium-dependent glucose transporter 1 (SGLT1), G protein-coupled receptors (GPR), and others have been identified on EECs that trigger hormone release. EECs express two unrelated GPR families: the T1R and T2R receptor families [14]. The three T1R subtypes heterodimerize to sense sweetness (T1R2 and T1R3) and amino acids (T1R1 and T1R3), whereas the T2R family consisting of 25 subtypes act as bitter sensors and interact with the small G protein a-gustducin [14-17]. Other GPRs such as the long-chain fatty acid receptors FFA1 (GPR40) and GPR120, or the bile acid receptor GPR131, are exclusively expressed on EECs; others, e.g. the short-chain fatty acid receptor FFA3 (GRP41), are also expressed in adipose and pancreatic tissue (fig. 2) [18-20]. In addition, 
Table 1. Summary of EEC subsets and their main localization, hormone secretion, function, stimuli and chemosensors in humans

\begin{tabular}{|c|c|c|c|c|c|}
\hline $\begin{array}{l}\text { Cell } \\
\text { type }\end{array}$ & $\begin{array}{l}\text { Main } \\
\text { localization }\end{array}$ & $\begin{array}{l}\text { Secretion } \\
\text { products }\end{array}$ & Principal effects & Main stimuli & $\begin{array}{l}\text { Luminal } \\
\text { receptors }\end{array}$ \\
\hline G cells & $\begin{array}{l}\text { Pyloric antrum } \\
\text { Duodenum }\end{array}$ & Gastrin & $\begin{array}{l}\text { Stimulation of acid secretion, production of } \\
\text { pepsinogen }\end{array}$ & $\begin{array}{l}\text { Expansion of the stomach, } \\
\text { alcohol, caffeine, protein } \\
\text { Inhibition by somatostatin, } \\
\text { secretin, GIP, NT, low pH }\end{array}$ & $\begin{array}{l}\text { CaSR, GPRC6A } \\
\text { LPAR5 }\end{array}$ \\
\hline $\begin{array}{l}\mathrm{P} / \mathrm{D}_{1^{-}} \\
\text {like cells }\end{array}$ & Stomach & $\begin{array}{l}\text { Ghrelin } \\
\text { Obestatin } \\
\text { Nesfatin-1 }\end{array}$ & $\begin{array}{l}\text { Stimulation of food intake, long-term body weight } \\
\text { control } \\
\text { Reduce food intake and body weight? } \\
\text { Reduce food intake, body weight/induce insulin } \\
\text { secretion }\end{array}$ & $\begin{array}{l}\text { Fasting/inhibition: carbohydrates } \\
\text { and lipids (LCFA) }\end{array}$ & $\begin{array}{l}\text { T1R1-T1R3, } \\
\text { T2Rs }\end{array}$ \\
\hline $\mathrm{D}$ cells & $\begin{array}{l}\text { Stomach, } \\
\text { intestine }\end{array}$ & Somatostatin & $\begin{array}{l}\text { Inhibition of GI hormone (e.g. gastrin) release, } \\
\text { biliary secretion and exocrine function of the gut and } \\
\text { pancreas, modulation of insulin release pancreas }\end{array}$ & & $\begin{array}{l}\text { CaR, GPRC6A } \\
\text { LPAR5 }\end{array}$ \\
\hline$S$ cells & Duodenum & Secretin & $\begin{array}{l}\text { Stimulation of pancreatic bicarbonate secretion, } \\
\text { inhibition of gastric acid secretion, colonic } \\
\text { contraction and motility, trigger insulin secretion }\end{array}$ & $\begin{array}{l}\text { Low duodenal } \mathrm{pH} \\
\text { Digested proteins }\end{array}$ & Acid receptor \\
\hline $\mathrm{M}$ cells & $\begin{array}{l}\text { Proximal small } \\
\text { intestine }\end{array}$ & Motilin & Enhancement of gut motility & $\begin{array}{l}\text { Lipids, gastric distension, bile } \\
\text { acids, low } \mathrm{pH} \text { in the duodenum, } \\
\text { neuronal nerves, serotonin }\end{array}$ & Bile receptors \\
\hline K cells & $\begin{array}{l}\text { Proximal small } \\
\text { intestine }\end{array}$ & Xenin & $\begin{array}{l}\text { Enhancement of insulin secretion inhibition of } \\
\text { gastric emptying and gastric acid secretion, } \\
\text { reduction of LPL activity in adipose tissue } \\
\text { Glucose homeostasis, reduction in food intake }\end{array}$ & $\begin{array}{l}\text { Carbohydrates, fatty acids, } \\
\text { proteins (certain amino acids) }\end{array}$ & $\begin{array}{l}\text { a-Gustducin } \\
\text { SGLT1, FFA1, } \\
\text { GRP120, } \\
\text { GRP119 }\end{array}$ \\
\hline \multirow{4}{*}{ L cells } & & GLP-2 & $\begin{array}{l}\text { Increase in mucosal growth, hexose transport; } \\
\text { inhibition of food intake }\end{array}$ & Bile acids & GPR131 \\
\hline & & Glicentin & $\begin{array}{l}\text { Increase in mucosal growth; inhibition of gastric } \\
\text { emptying }\end{array}$ & $\begin{array}{l}\text { Lipids }(\text { LCFA, not MCT) }> \\
\text { protein }\end{array}$ & a-Gustducin \\
\hline & & PYY & $\begin{array}{l}\text { Reduction in gastric emptying, intestinal transit, } \\
\text { food intake and appetite; increase in water and } \\
\text { electrolyte absorption }\end{array}$ & Low-carbohydrate diet & $\begin{array}{l}\text { FFA2 } \\
\text { FFA3 }\end{array}$ \\
\hline & & OXM & $\begin{array}{l}\text { Enhancement of insulin secretion, induction of } \\
\text { weight loss and energy expenditure }\end{array}$ & Lipids & GPR119 \\
\hline EC cells & $\begin{array}{l}\text { Stomach, small } \\
\text { and large } \\
\text { intestine }\end{array}$ & $5-\mathrm{HT}$ & $\begin{array}{l}\text { Increase in gastric and pancreatic secretion and } \\
\text { intestinal motility, accelerate intestinal transit, } \\
\text { regulate appetite } \\
\text { Insulin release }\end{array}$ & $\begin{array}{l}\text { Chemical }(\mathrm{pH}) \text {, mechanical, } \\
\text { neural stimulation } \\
\text { SCFA, glucose intake, gastrin }\end{array}$ & $\begin{array}{l}\text { FFA2, FFA3, } \\
\text { TLR, TRPA1, } \\
\text { toxin R }\end{array}$ \\
\hline
\end{tabular}

EEC types may have subgroups and contain different combinations of secretion products along the intestine, e.g., I and L cells may contain 5-HT. $\mathrm{CaSR}=$ Calcium-sensing receptor; $\mathrm{FA}=$ fatty acid $; \mathrm{FFAR}=$ fatty acid receptors; $\mathrm{LPAR}=$ lysophosphatidic acid receptor; TLR $=$ Toll-like receptor; $\mathrm{TRPA} 1=$ transient receptor potential ankyrin 1; LCFA = long-chain fatty acid; SCFA = short-chain fatty acid; $\mathrm{MCT}=$ medium-chain triglyceride; LPL = lipoproteinlipase. 
Fig. 2. Luminal stimulation of EEC hormone release. Luminal contents stimulate EECs (violet) via their taste receptors. These receptors are mainly located at the apical domain, but are also found at the lateral membrane of EECs (indicated by the red serpentine symbol) and sense bile acids, protein components, sugar, and lipids via, for example, calcium-sensing receptors (CaSR), SGLT1, or GPRs (indicated by pink boxes). Taste receptors signal through a-gustducin. Altogether, this initiates a signaling cascade with elevation of intracellular cAMP and calcium $\left(\mathrm{Ca}^{2+}\right)$ or PLC $\beta 2$ activation, triggers membrane depolarization via TRPM5, and activates voltage-gated $\mathrm{Ca}^{2+}$ channels. Elevated intracellular $\mathrm{Ca}^{2+}$ is the primary trigger of exocytosis and the release of peptide hormones from the EEC base. The released gut hormones can act with neighboring cells in a paracrine fashion, stimulate neuronal cells, or act as classical hormones via the bloodstream. LCFA = Long-chain fatty acid; SCFA = short-chain fatty acid. Adapted and modified according to Engelstoft et al. [89].

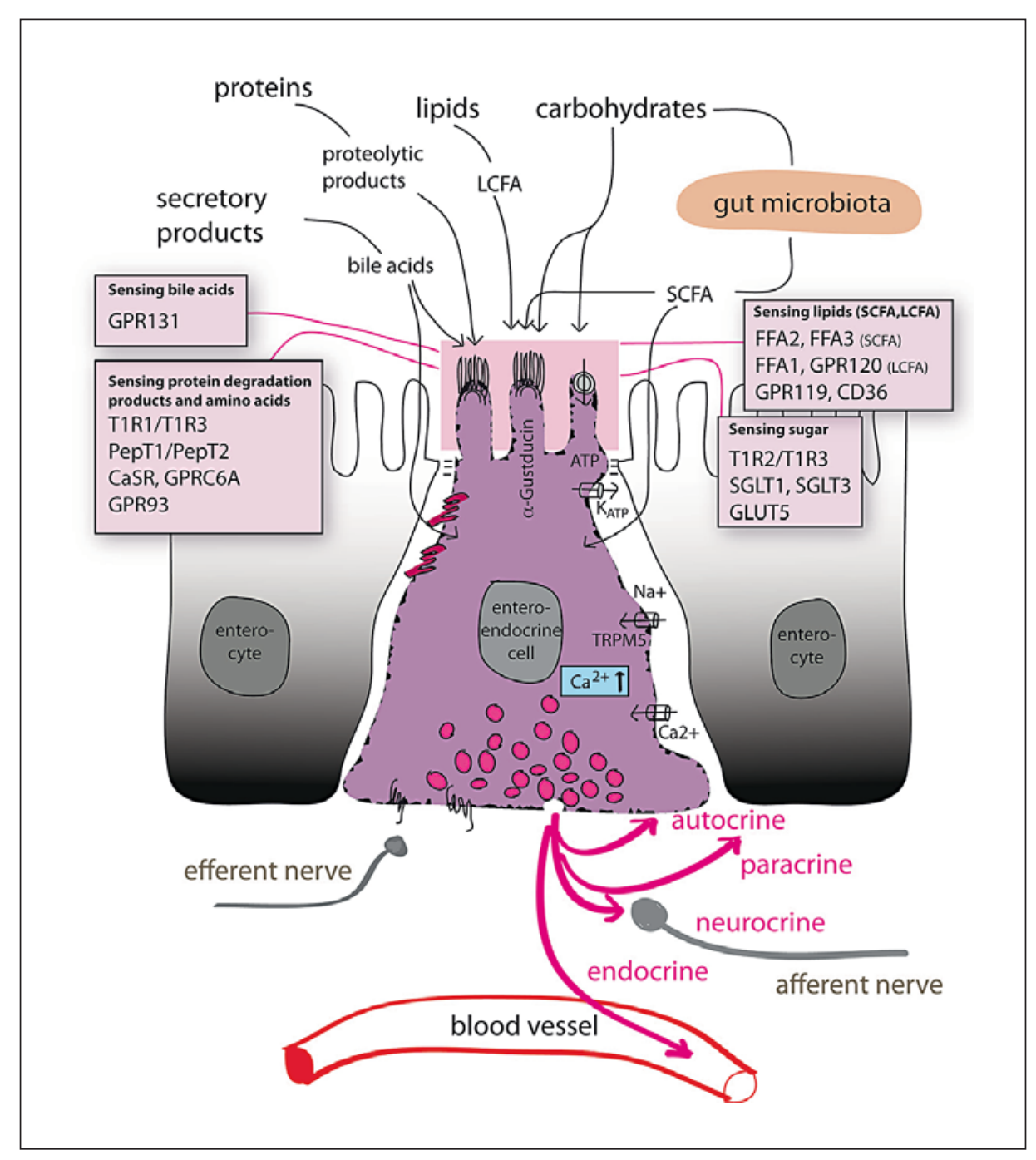

the expression of the chemosensing machinery differs among EEC subtypes; therefore, a different gut peptide release is induced according to the dietary intake and composition. This emphasizes the impact of EECs as sensors of the gut luminal content and regulators of digestion, and suggests a major role in the regulation of appetite and satiety.

\section{How EECs Regulate Appetite and Satiation}

Historically, with the discovery of secretin in 1902 [2] gut endocrinology was the first field in endocrinology. The discovery of secretin was followed by John Edkins' finding of gastrin in 1905 [4], after which Ivy and Oldberg
[3] described CCK in 1928 as a stimulant of the gallbladder [21]. The anatomical dissemination and the variety of EEC subsets hampered research for many years. In the following section we focus on the interactions of EEC subtypes towards nutrients and the physiological consequences on appetite and intestinal satiation (table 1).

\section{P/D -Like Cells: Acyl Ghrelin, Des-Acyl Ghrelin, Obestatin, and Nesfatin-1}

$\mathrm{P} / \mathrm{D}_{1}$-like cells are distributed throughout the mucosal layer and account for $20 \%$ of the endocrine cell population in oxyntic glands [22]. Of note, in other species, such as rodents, these cells are termed X/A-like cells. They are 
mainly located in the gastric fundus and have also been found in lower densities in the intestinal tract [22]. In the stomach they have a round shape without contact to the lumen. They release acyl ghrelin, des-acyl ghrelin, and obestatin, which are all encoded from the same gene, and in addition nesfatin-1. These hormones are involved in body weight homeostasis with a stimulatory role on food intake for acyl ghrelin and an inhibitory effect of des-acyl ghrelin and nesfatin-1 [23]. Thus $\mathrm{P} / \mathrm{D}_{1}$-like cells have the unique yin and yang properties to mediate opposed effects and may mediate hunger or satiety depending on the released hormones [23]. Of note, $\mathrm{P} / \mathrm{D}_{1}$-like cells store these peptide hormones in different vesicles.

The 28-amino-acid peptide ghrelin has a unique fatty acid modification on the third amino acid, which is essential for the binding to the ghrelin receptor. This acylation of the precursor proghrelin peptide is achieved by the enzyme ghrelin $\mathrm{O}$-acyltransferase during posttranslational modification in $\mathrm{P} / \mathrm{D}_{1}$-like cells, but also later on in the plasma [24]. The ratio of acyl ghrelin and total ghrelin in the plasma varies between 1:5 and 1:19 [23]. Acyl ghrelin is the only known peripheral hunger-inducing hormone (orexin), which is released into the plasma during fasting. Shortterm exogenous administration of acyl ghrelin effectively stimulates appetite and energy intake in humans [25, 26]. In addition, there is also evidence that it may stimulate gastric motility and emptying without inducing emesis [25]. Ingestion of monosaccharides and complex carbohydrates [27, 28], as well as long-chain fatty acids [29], reduces ghrelin expression, whereas protein stimulates ghrelin expression. However, after oral glucose tolerance testing there is no significant reduction of acyl ghrelin in obese children compared to lean children [30]. Distension of the stomach is not sufficient to regulate ghrelin response, but postgastric feedback via glucose-dependent insulinotropic peptide (GIP) influences ghrelin secretion [27].

Obestatin is a 23-amino-acid peptide and an alternative splicing product of proghrelin. In contrast to ghrelin, obestatin has anorexigenic effects and reduces gastric emptying [31]. The gastric peptide content and the plasma level of obestatin does not seem to be regulated by the metabolic state $[23,31,32]$. However, obestatin increased significantly during weight reduction in an intervention program [33], and after bypass surgery obestatin levels remained stable while the ratio of ghrelin and obestatin decreased [32].

The 82-amino-acid peptide nucleobindin-2/nesfatin-1 was described as an inhibitor of food intake. Repeated administrations reduced weight gain along with a reduction in fat mass [23]. There is also evidence that it decreases dark-phase feeding by inducing satiation and satiety [34].

Obese humans have lower ghrelin levels compared to lean individuals [35]. In addition, obese patients have higher ghrelin O-acyltransferase protein levels in the plasma compared to normal-weight controls [24], thereby maintaining the unfavorable situation of obesity. Recent data provide evidence for a differential regulation of $\mathrm{P} / \mathrm{D}_{1^{-}}$ like cell hormones to counteract further body weight increase. Nesfatin-1 expression increases in obese patients with rising BMI, while acyl ghrelin expression decreases in $\mathrm{P} / \mathrm{D}_{1}$-like cells [36]. Thus, there are significant findings indicating that $\mathrm{P} / \mathrm{D}_{1}$-like cells are involved in the regulation of hunger, satiation, and body weight regulation.

\section{Cells: CCK}

The triangular-shaped I cells are opened towards the intestinal lumen and contain in their basal-located granules the 27-amino-acid polypeptide CCK [37]. I cells reside in the duodenal and jejunal mucosa. Intestinal CCK secretion is stimulated in response to fat- and proteincontaining meals. In order to facilitate nutrient digestion, CCK inhibits gastric emptying, reduces gastric acid secretion, and stimulates gallbladder contraction as well as pancreatic enzyme secretion. CCK was the first anorexigen gut hormone [21] shown to modulate appetite in humans. In accordance, exogenous administration of CCK decreases meal size in a dose-dependent manner, which is even more efficient in a distended stomach $[38,39]$. However, this effect is only temporary as CCK is rapidly degraded with an approximately 13-min half-life in human plasma.

I cells secrete CCK in response to fat, especially fatty acids, and the secretion critically depends on fatty acid length. I cells detect long-chain fatty acids via FFA1 (GPR40) [40], while medium-chain triglycerides do not activate I cells. Protein in general, specifically hydrolyzed proteins and amino acids are strong inducers of CCK release in I cells via calcium-sensing receptors [41]. In contrast, I cells barely respond towards carbohydrates and the sensing mechanism is not yet known [42].

Pancreatic lipase insufficiency is associated with a poor CCK response to triglycerides, explaining at least in part the increased appetite and food ingestion in humans suffering from pancreatic lipase insufficiency [43]. 


\section{Cells: PYY, GLP-1, GLP-2, OXM, and Glicentin}

L cells are open-type intestinal cells found scattered mainly in the distal ileum and colon. They received their name due to their L shape with a long extending base; however, in the colon they have a spindle- or sigmoidallike form. Like I cells, they express fatty acid receptors. They synthesize a large precursor protein known as preproglucagon, which is processed into glucagon, GLP-1, GLP-2, OXM, and glicentin. In addition, $L$ cells synthesize PYY. All five hormones induce an 'ileal break' by inhibiting gastric emptying and decelerating ileal transit, thereby decreasing food intake and preventing malabsorption and postprandial metabolic disturbances. In addition, GLP-1 and OXM are released after a meal and play a role in distal intestinal satiety signaling.

PYY is secreted as a 36 -amino-acid peptide, which is enzymatically truncated by dipeptidyl peptidase- 4 into $\mathrm{PYY}_{3-36}$ [44]. Full-length $\mathrm{PYY}_{1-36}$ reduces gastric emptying and, similar to GLP-2, induces an ileal break by increasing GI transit time and facilitates nutrient absorption in the small intestine [44]. $\mathrm{PYY}_{3-36}$ is the major form released from $\mathrm{L}$ cells in proportion to caloric intake, and possess anorexigenic properties by reducing food intake and appetite [44-46]. Interestingly, endogenous PYY responses are reduced during oral glucose testing in obese children and after standard test meals in adults compared to normal-weight subjects [30,47]. Moreover, double the caloric meal content is required in obese subjects to achieve equivalent PYY levels observed in normal-weight subjects [47]. Thus, impaired PYY release may relate to reduced satiety in obese subjects and contribute in the pathogenesis of obesity. $\mathrm{PYY}_{3-36}$ selectively binds with high affinity to the neuropeptide $Y$ subtype 2 receptor located in the arcuate nucleus in the brain and on the vagus nerve [48]. Exogenous infusion of an active $\mathrm{PYY}_{3-36}$ peptide reduces food intake in normal-weight and obese humans $[35,45]$. In addition, PYY infusion lowers ghrelin levels during and $3 \mathrm{~h}$ after infusion of PYY [45]. PYY ${ }_{3-36}$ levels increase within $30 \mathrm{~min}$ after a meal and remain elevated for up to $6 \mathrm{~h}$ [45]. The sustained PYY secretion is supposed to be mediated by luminal stimulation of L cells. In accordance, carbohydrates, long-chain fatty acids, and especially protein-rich diets stimulate PYY release and in turn slow down gastric emptying $[29,49]$. In particular, $\mathrm{PYY}_{3-36}$ has more of an effect on food intake for the subsequent $12 \mathrm{~h}$ than the postprandial reduction in food intake [46]. Indeed, circulating levels of PYY are reduced in obesity and may support increased food intake $[45,50]$. In addition, PYY levels decrease during midpuberty in both genders, which correlates inversely with the growth hormone levels and may stimulate food intake to promote pubertal growth [51].

In 1985 the potent insulinotropic actions of the 30 -amino acid peptide GLP-1 were first described [52]. Gut hormones which amplify nutrient-induced insulin secretion in response to food intake such as GLP-1, are named incretin hormones [53]. GLP-1 induces pancreatic $\beta$-cell mass, increases transcription and secretion of insulin, and suppresses glucagon secretion, thereby contributing to glucose homeostasis [53]. In addition, it decelerates gastric emptying and acid secretion.

GLP-1 secretion and plasma levels increase after a meal according to the amount and composition of food intake [54]. In accordance, fat- or carbohydrate-containing meals strongly induce GLP-1 release [49], especially during weight loss [55], but is negatively correlated to BMI $[54,55]$. Thus, a decrease in GLP-1 secretion may contribute to the development of obesity [54]. GLP-1 is also widely expressed in the human brain and acts directly on GLP-1 receptors in the brain [56]. It is clear that the central GLP-1 system is important in appetite regulation; however, its relation to food intake is unclear [57]. In fact, there is also evidence that peripheral GLP-1 directly activates areas of the brain and is implicated in satiation [58]. Indeed, peripheral GLP-1 administration exerts anorexigenic properties by enhancing the sensation of satiety and reduces food intake after an energy-fixed breakfast [59]. Furthermore, physical exercise leads to an increase in GLP-1 [60]. However, humoral GLP-1 is rapidly degraded by dipeptidyl peptidase- 4 and very little peptide actually reaches the circulation (half-life: $1.5-5 \mathrm{~min}$ ). Thus, GLP-1 released from L cells may stimulate peripheral GLP-1 receptors located on vagal sensor afferents before entering the capillaries or activate sensory neurons in the hepatoportal region and liver [56].

The 33-amino-acid peptide GLP-2 is co-secreted with GLP-1 from L cells in response to nutrient ingestion. Like GLP-1, it is also rapidly degraded by dipeptidyl peptidase-4 [61]. GLP-2 reduces gastric motility and acid secretion [61], increases hexose transport activity, and is supposed to inhibit food intake [62]. In addition, GLP-2 has specific trophic properties, e.g. it enhances intestinal epithelial barrier function [63] and promotes mucosal growth and cell survival [61]. Furthermore, GLP-2 is suggested to reduce ingestion and slow down the GI food transit to increase nutrient absorption in the small intestine.

Like GLP-1, the 37-amino-acid OXM is derived from a preproglucagon precursor and contains the 29-aminoacid sequence of glucagon. It was named OXM as it in- 
hibits gastric acid secretion. OXM increases after calorie intake and reduces food intake and appetite in humans [64]. These effects are not surprising since OXM signals through the GLP-1 receptor. Chronic administration of OXM causes weight loss and increases energy expenditure [65].

Finally, glicentin, the largest molecule processed from proglucagon, consists of 69 amino acid residues. It is cosecreted from L cells, along with GLP-1, GLP-2, and OXM. Like OXM, it possesses the sequence of glucagon. The biological actions include insulin secretion, inhibition of gastric acid secretion, gastric emptying, and stimulation of mucosal enterocyte proliferation [66].

Taken together, hormones released by L cells induce intestinal satiation signals, increase GI-transit time, and reduce food intake and appetite.

\section{K Cells: GIP}

$\mathrm{K}$ cells are open-type EECs located along the intestinal tract with an increase in the duodenum-producing GIP and xenin $[67,68]$. They may coexpress GLP-1 in the midintestine and are therefore also referred to as $\mathrm{K} / \mathrm{L}$ or $\mathrm{L} / \mathrm{K}$ cells.

As an incretin, GIP is responsible for glucose-induced insulin secretion, but not for food intake [69]. However, GIP receptor knockout mice are resistant to obesity [70]. GIP receptors are expressed in different tissues and may be responsible for the multifaceted effects of the 42 -amino-acid peptide GIP. Its secretion is stimulated in a mealdependent manner by fat and carbohydrates through the action of SGLT1, FFA1 (GPR40), GPR120, and GPR119 [71]. In particular, fatty acids are sensed by FFA1 (GPR40), GPR120, and GPR119 receptors on K cells. In addition, there is evidence that proteins also induce GIP secretion, especially certain amino acids. The density of $\mathrm{K}$ cells corresponds to the GIP plasma level and may increase under conditions of a high-fat diet. However, to avoid an inappropriate insulinotropic response, this effect depends on the parallel administration of fat and glucose [71]. Obesity is associated with elevated GIP levels and increased $\mathrm{K}$ cell secretory response in humans [72, 73]. Accordingly, GIP mediates anabolic effects in adipose tissue, including stimulation of glucose uptake and fatty acid synthesis and deposition $[74,75]$. It represents a link between overnutrition and obesity as GIP receptor antagonism has reversed obesity and metabolic changes in high-fat-fed mice [76].

K cells also secrete a 25 -amino-acid neurotensin (NT)related peptide, called xenin, which is involved in glucose homeostasis. Xenin-25 increases the insulinotropic response to GIP, but has no effect when administered alone [77]. Xenin is structurally similar to NT, which is a satiety factor [78]. Recent studies suggest that xenin reduces food intake through a leptin- and melanocortin-independent mechanism [79].

\section{N Cells: NT}

$\mathrm{N}$ cells are mainly found in the jejunum and ileum of the GI tract. They secrete NT composed of 13 amino acids in response to intraluminal lipids. The 13 -amino-acid peptide NT stimulates pancreatic and biliary secretion, inhibits gastric and small intestinal motility, and enhances fatty acid transport [80]. In addition, NT is a growth factor for GI tissues, e.g. the pancreas, colon, and small bowel [81]. NT receptor 1 is expressed in the intestine and brain and mediates the metabolic effect of NT and xenin [82]. Thus, NT may have the potential to ameliorate obesity by reducing appetite.

\section{Cells: Somatostatin}

D cells are distributed throughout the GI tract with the highest frequency in the duodenum. D cells in the large intestine have a spindle shape with a small apical process and a wider basal extension, and differ from the appearance in the stomach. The large secretory vesicles contain somatostatin-14 and -28. It is the major inhibitory hormone of the GI tract and decreases the release of GI hormones and exocrine functions of the GI tract and pancreas by binding to 1 of the 5 existing somatostatin receptors which are ubiquitously expressed with high expression levels in the GI tract, pancreas, and brain $[76,83]$.

\section{EC Cells: 5-HT}

EC cells are the most common EEC type and are distributed throughout the GI tract. They have a pyramid shape with a slender apical process reaching the luminal surface. Interestingly, they store most of the entire body's 5 -HT content in their granules. EC cells secrete 5 -HT predominantly after neural, but also after chemical, stimulation, e.g. short-chain fatty acids may release 5-HT. It may act in an autocrine and/or paracrine, endocrine, and neurocrine manner, and increases secretion and intestinal motility, accelerates the intestinal transit, and regulates 
appetite. These effects are mediated by the 5-HT receptor family. Targeting 5 -HT receptors may provide a suitable strategy to regulate appetite and ingestive behavior. Administration of a $5-\mathrm{HT}_{2 \mathrm{C}}$ receptor agonist in mice increases anorectic pro-opiomelanocortin mRNA and reduces body weight, body fat ratio, and initial food intake [84]. However, mice lacking the melanocortin 4 receptor do not respond to a $5-\mathrm{HT}_{2 \mathrm{C}}$ receptor agonist, indicating that melanocortins acting on the melanocortin 4 receptor are necessary to mediate the effect on food intake downstream of $5-\mathrm{HT}_{2 \mathrm{C}}$ [84]. Of note, lorcaserin, a selective $5-\mathrm{HT}_{2 \mathrm{C}}$ receptor agonist, which has recently been approved by the FDA for the therapy of obesity, induces weight loss in obese humans $[85,86]$.

\section{S Cells: Secretin}

$S$ cells secrete secretin and reside in the duodenum and in smaller numbers also in the jejunum and small intestine [2]. The 27-amino-acid peptide secretin is secreted postprandially into the circulation and regulates $\mathrm{pH}$ in the duodenum by inhibiting gastric acid secretion, delaying gastric emptying, and stimulating bicarbonate fluid production from the pancreas and liver. Secretin is now considered a neurally active peptide that exhibits a role in appetite regulation and fatty acid metabolism because central and peripheral administration of secretin inhibits food intake in mice by stimulating the melanocortin system [87].

\section{Conclusion}

This review demonstrates that EECs take on a special position in sensing the luminal contents and being involved in the complex regulation of food intake, appetite, and satiation. The hormones released by EECs in response to physical and chemical stimuli like ghrelin, nesfatin-1, GIP, CCK, GLP-1, OXM, PYY, and even secretin influence not only gastric emptying and intestinal transit, the release of digestive enzymes, and pancreatic insulin secretion, but also appetite and satiety, thereby ultimately influencing body weight. Indeed, peripheral administration of gut hormones such as nesfatin-1, CCK, GLP-1, OXM, PYY, 5-HT, and secretin reduces food intake in humans. In addition, gut hormone secretion in response to food intake differs between obese and lean subjects. Accordingly, gut hormone levels are altered in obesity, e.g. ghrelin and PYY levels are reduced and GIP and nesfatin-1 levels are elevated and probably promote the unfavorable state of obesity. In part 2 of our review, we will discuss the potential of EECs and their hormones as targets for new treatment strategies.

\section{Medline Search Strategy}

Articles were searched using the following keywords: enteroendocrine cells, obesity, taste receptors, satiation, gastrointestinal hormones, microbiota, differentiation, etc.

\section{References}

1 Vanden Berghe P, Janssen P, Kindt S, Vos R, Tack J: Contribution of different triggers to the gastric accommodation reflex in humans. Am J Physiol Gastrointest Liver Physiol 2009; 297:G902-G906.

2 Bayliss WM, Starling EH: The mechanism of pancreatic secretion. J Physiol 1902;28:325353.

-3 Ivy A, Oldberg E: A hormone mechanism for gallbladder contraction and evacuation. Am J Physiol 1928;86:599-613.

4 Modlin IM, Sachs G, Wright N, Kidd M: Edkins and a century of acid suppression. Digestion 2005;72:129-145.

5 Gibbs J, Young RC, Smith GP: Cholecystokinin decreases food intake in rats. J Comp Physiol Psychol 1973;84:488-495.

6 6 Schwartz MW, Woods SC, Porte D Jr, Seeley RJ, Baskin DG: Central nervous system control of food intake. Nature 2000;404:661671
7 Rindi G, Leiter AB, Kopin AS, Bordi C, Solcia $\mathrm{E}$ : The 'normal' endocrine cell of the gut: changing concepts and new evidences. Ann NY Acad Sci 2004;1014:1-12.

-8 Barker N, van Es JH, Kuipers J, Kujala P, van den Born M, Cozijnsen M, Haegebarth A, Korving J, Begthel H, Peters PJ, Clevers H: Identification of stem cells in small intestine and colon by marker gene Lgr5. Nature 2007; 449:1003-1007.

-9 Li HJ, Ray SK, Singh NK, Johnston B, Leiter $\mathrm{AB}$ : Basic helix-loop-helix transcription factors and enteroendocrine cell differentiation. Diabetes Obes Metab 2011;13(suppl 1):5-12.

10 Schonhoff SE, Giel-Moloney M, Leiter AB: Minireview: Development and differentiation of gut endocrine cells. Endocrinology 2004; 145:2639-2644

11 Tolhurst G, Reimann F, Gribble FM: Intestinal sensing of nutrients. Handb Exp Pharmacol 2012;209:309-335.
12 Breer H, Eberle J, Frick C, Haid D, Widmayer P: Gastrointestinal chemosensation: chemosensory cells in the alimentary tract. Histochem Cell Biol 2012;138:13-24.

13 Bozkurt A, Oktar BK, Kurtel H, Alican I, Coskun T, Yegen BC: Capsaicin-sensitive vagal fibres and 5-HT3-, gastrin releasing peptide- and cholecystokinin A-receptors are involved in distension-induced inhibition of gastric emptying in the rat. Regul Pept 1999; 83:81-86.

14 Wauson EM, Lorente-Rodriguez A, Cobb MH: Minireview: Nutrient sensing by G protein-coupled receptors. Mol Endocrinol 2013; 27:1188-1197.

15 Cummings DE, Overduin J: Gastrointestinal regulation of food intake. J Clin Invest 2007; 117:13-23. 
16 Sternini C, Anselmi L, Rozengurt E: Enteroendocrine cells: a site of 'taste' in gastrointestinal chemosensing. Curr Opin Endocrinol Diabetes Obes 2008;15:73-78.

$\checkmark 17$ Hofer D, Puschel B, Drenckhahn D: Taste receptor-like cells in the rat gut identified by expression of alpha-gustducin. Proc Natl Acad Sci USA 1996;93:6631-6634.

-18 Reimann F, Habib AM, Tolhurst G, Parker HE, Rogers GJ, Gribble FM: Glucose sensing in L cells: a primary cell study. Cell Metab 2008;8:532-539.

19 Samuel BS, Shaito A, Motoike T, Rey FE, Backhed F, Manchester JK, Hammer RE, Williams SC, Crowley J, Yanagisawa M, Gordon JI: Effects of the gut microbiota on host adiposity are modulated by the short-chain fattyacid binding $G$ protein-coupled receptor, Gpr41. Proc Natl Acad Sci USA 2008; 105 : 16767-16772.

20 Brown AJ, Jupe S, Briscoe CP: A family of fatty acid binding receptors. DNA Cell Biol 2005;24:54-61.

-21 Liddle RA, Goldfine ID, Rosen MS, Taplitz RA, Williams JA: Cholecystokinin bioactivity in human plasma. Molecular forms, responses to feeding, and relationship to gallbladder contraction. J Clin Invest 1985;75:1144-1152.

22 Date Y, Kojima M, Hosoda H, Sawaguchi A, Mondal MS, Suganuma T, Matsukura S, Kangawa K, Nakazato M: Ghrelin, a novel growth hormone-releasing acylated peptide, is synthesized in a distinct endocrine cell type in the gastrointestinal tracts of rats and humans. Endocrinology 2000;141:4255-4261.

-23 Stengel A, Tache Y: Yin and yang - the gastric $\mathrm{X} / \mathrm{A}$-like cell as possible dual regulator of food intake. J Neurogastroenterol Motil 2012;18: 138-149.

24 Goebel-Stengel M, Hofmann T, Elbelt U, Teuffel P, Ahnis A, Kobelt P, Lambrecht NW, Klapp BF, Stengel A: The ghrelin activating enzyme ghrelin-O-acyltransferase (GOAT) is present in human plasma and expressed dependent on body mass index. Peptides 2013; 43:13-19.

25 Garin MC, Burns CM, Kaul S, Cappola AR: Clinical review: the human experience with ghrelin administration. J Clin Endocrinol Metab 2013;98:1826-1837.

-26 Wren AM, Seal LJ, Cohen MA, Brynes AE, Frost GS, Murphy KG, Dhillo WS, Ghatei MA, Bloom SR: Ghrelin enhances appetite and increases food intake in humans. J Clin Endocrinol Metab 2001;86:5992.

$\checkmark 27$ Blom WA, Lluch A, Vinoy S, Stafleu A, van den Berg R, Holst JJ, Kok FJ, Hendriks HF: Effects of gastric emptying on the postprandial ghrelin response. Am J Physiol Endocrinol Metab 2006;290:E389-E395.

-28 Blom WA, Stafleu A, de Graaf C, Kok FJ, Schaafsma G, Hendriks HF: Ghrelin response to carbohydrate-enriched breakfast is related to insulin. Am J Clin Nutr 2005;81: 367-375.
29 Feinle-Bisset C, Patterson M, Ghatei MA, Bloom SR, Horowitz M: Fat digestion is required for suppression of ghrelin and stimulation of peptide YY and pancreatic polypeptide secretion by intraduodenal lipid. Am J Physiol Endocrinol Metab 2005;289:E948-E953.

30 Roth CL, Bongiovanni KD, Gohlke B, Woelfle $\mathrm{J}$ : Changes in dynamic insulin and gastrointestinal hormone secretion in obese children. J Pediatr Endocrinol Metab 2010;23:12991309.

-31 Zhang JV, Ren PG, Avsian-Kretchmer O, Luo CW, Rauch R, Klein C, Hsueh AJ: Obestatin, a peptide encoded by the ghrelin gene, opposes ghrelin's effects on food intake. Science 2005;310:996-999.

32 Roth CL, Reinehr T, Schernthaner GH, Kopp HP, Kriwanek S, Schernthaner G: Ghrelin and obestatin levels in severely obese women before and after weight loss after Roux-en-Y gastric bypass surgery. Obes Surg 2009;19: 29-35.

33 Reinehr T, de Sousa G, Roth CL: Obestatin and ghrelin levels in obese children and adolescents before and after reduction of overweight. Clin Endocrinol (Oxf) 2008;68:304310.

34 Goebel M, Stengel A, Wang L, Tache Y: Central nesfatin-1 reduces the nocturnal food intake in mice by reducing meal size and increasing inter-meal intervals. Peptides 2011; 32:36-43.

35 le Roux CW, Patterson M, Vincent RP, Hunt C, Ghatei MA, Bloom SR: Postprandial plasma ghrelin is suppressed proportional to meal calorie content in normal-weight but not obese subjects. J Clin Endocrinol Metab 2005; 90:1068-1071.

- 36 Stengel A, Hofmann T, Goebel-Stengel M, Lembke V, Ahnis A, Elbelt U, Lambrecht NW, Ordemann J, Klapp BF, Kobelt P: Ghrelin and NUCB2/nesfatin-1 are expressed in the same gastric cell and differentially correlated with body mass index in obese subjects. Histochem Cell Biol 2013;139:909-918.

- 37 Liddle RA: Cholecystokinin cells. Annu Rev Physiol 1997;59:221-242.

38 Kissileff HR, Pi-Sunyer FX, Thornton J, Smith GP: C-terminal octapeptide of cholecystokinin decreases food intake in man. Am J Clin Nutr 1981;34:154-160.

39 Kissileff HR, Carretta JC, Geliebter A, PiSunyer FX: Cholecystokinin and stomach distension combine to reduce food intake in humans. Am J Physiol Regul Integr Comp Physiol 2003;285:R992-R998.

40 Liou AP, Chavez DI, Espero E, Hao S, Wank SA, Raybould HE: Protein hydrolysate-induced cholecystokinin secretion from enteroendocrine cells is indirectly mediated by the intestinal oligopeptide transporter PepT1. Am J Physiol Gastrointest Liver Physiol 2011; 300:G895-G902.
41 Wang Y, Chandra R, Samsa LA, Gooch B, Fee BE, Cook JM, Vigna SR, Grant AO, Liddle RA: Amino acids stimulate cholecystokinin release through the $\mathrm{Ca}^{2+}$-sensing receptor. Am J Physiol Gastrointest Liver Physiol 2011; 300:G528-G537.

42 Gerspach AC, Steinert RE, Schonenberger L, Graber-Maier A, Beglinger C: The role of the gut sweet taste receptor in regulating GLP-1, PYY, and CCK release in humans. Am J Physiol Endocrinol Metab 2011;301:E317E325.

43 Karhunen LJ, Juvonen KR, Huotari A, Purhonen AK, Herzig KH: Effect of protein, fat, carbohydrate and fibre on gastrointestinal peptide release in humans. Regul Pept 2008; 149: 70-78.

44 Murphy KG, Dhillo WS, Bloom SR: Gut peptides in the regulation of food intake and energy homeostasis. Endocr Rev 2006;27:719727.

45 Batterham RL, Cohen MA, Ellis SM, Le Roux CW, Withers DJ, Frost GS, Ghatei MA, Bloom SR: Inhibition of food intake in obese subjects by peptide $\mathrm{YY}_{3-36}$. N Engl J Med 2003;349:941-948.

46 Batterham RL, Cowley MA, Small CJ, Herzog H, Cohen MA, Dakin CL, Wren AM, Brynes AE, Low MJ, Ghatei MA, Cone RD, Bloom SR: Gut hormone PYY(3-36) physiologically inhibits food intake. Nature 2002;418:650654.

47 le Roux CW, Batterham RL, Aylwin SJ, Patterson M, Borg CM, Wynne KJ, Kent A, Vincent RP, Gardiner J, Ghatei MA, Bloom SR: Attenuated peptide YY release in obese subjects is associated with reduced satiety. Endocrinology 2006;147:3-8.

48 Koda S, Date Y, Murakami N, Shimbara T, Hanada T, Toshinai K, Niijima A, Furuya M, Inomata $\mathrm{N}$, Osuye $\mathrm{K}$, Nakazato $\mathrm{M}$ : The role of the vagal nerve in peripheral $\mathrm{PYY}_{3-36}$-induced feeding reduction in rats. Endocrinology 2005; 146:2369-2375.

49 Gibbons C, Caudwell P, Finlayson G, Webb DL, Hellstrom PM, Naslund E, Blundell JE: Comparison of postprandial profiles of ghrelin, active GLP-1, and total PYY to meals varying in fat and carbohydrate and their association with hunger and the phases of satiety. J Clin Endocrinol Metab 2013;98:E847E855.

50 Roth CL, Enriori PJ, Harz K, Woelfle J, Cowley MA, Reinehr T: Peptide YY is a regulator of energy homeostasis in obese children before and after weight loss. J Clin Endocrinol Metab 2005;90:6386-6391.

51 Lloyd B, Ravi P, Mendes N, Klibanski A, Misra M: Peptide YY levels across pubertal stages and associations with growth hormone. J Clin Endocrinol Metab 2010;95:29572962.

-52 Schmidt WE, Siegel EG, Creutzfeldt W: Glucagon-like peptide-1 but not glucagon-like peptide-2 stimulates insulin release from isolated rat pancreatic islets. Diabetologia 1985; 28:704-707. 
53 Drucker DJ: Incretin action in the pancreas: potential promise, possible perils, and pathological pitfalls. Diabetes 2013;62:33163323.

54 Holst JJ: The physiology of glucagon-like peptide 1. Physiol Rev 2007;87:1409-1439.

-55 Verdich C, Toubro S, Buemann B, Lysgard Madsen J, Juul Holst J, Astrup A: The role of postprandial releases of insulin and incretin hormones in meal-induced satiety - effect of obesity and weight reduction. Int J Obes Relat Metab Disord 2001;25:1206-1214.

56 Holst JJ: Incretin hormones and the satiation signal. Int J Obes (Lond) 2013;37:1161-1168.

57 Vrang N, Larsen PJ: Preproglucagon derived peptides GLP-1, GLP-2 and oxyntomodulin in the CNS: role of peripherally secreted and centrally produced peptides. Prog Neurobiol 2010;92:442-462.

58 Pannacciulli N, Le DS, Salbe AD, Chen K, Reiman EM, Tataranni PA, Krakoff J: Postprandial glucagon-like peptide-1 (GLP-1) response is positively associated with changes in neuronal activity of brain areas implicated in satiety and food intake regulation in humans. Neuroimage 2007;35:511-517.

59 Flint A, Raben A, Astrup A, Holst JJ: Glucagon-like peptide 1 promotes satiety and suppresses energy intake in humans. J Clin Invest 1998;101:515-520.

-60 Ueda SY, Yoshikawa T, Katsura Y, Usui T, Fujimoto S: Comparable effects of moderate intensity exercise on changes in anorectic gut hormone levels and energy intake to high intensity exercise. J Endocrinol 2009;203:357364.

61 Burrin DG, Petersen Y, Stoll B, Sangild P: Glucagon-like peptide 2: a nutrient-responsive gut growth factor. J Nutr 2001;131:709712.

-62 Tang-Christensen M, Larsen PJ, Thulesen J, Romer J, Vrang N: The proglucagon-derived peptide, glucagon-like peptide-2, is a neurotransmitter involved in the regulation of food intake. Nat Med 2000;6:802-807.

-63 Benjamin MA, McKay DM, Yang PC, Cameron $\mathrm{H}$, Perdue MH: Glucagon-like peptide-2 enhances intestinal epithelial barrier function of both transcellular and paracellular pathways in the mouse. Gut 2000;47:112-119.

64 Cohen MA, Ellis SM, Le Roux CW, Batterham RL, Park A, Patterson M, Frost GS, Ghatei MA, Bloom SR: Oxyntomodulin suppresses appetite and reduces food intake in humans. J Clin Endocrinol Metab 2003;88:4696-4701.

-65 Wynne K, Park AJ, Small CJ, Meeran K, Ghatei MA, Frost GS, Bloom SR: Oxyntomodulin increases energy expenditure in addition to decreasing energy intake in overweight and obese humans: a randomised controlled trial. Int J Obes (Lond) 2006;30: 1729-1736.
66 Drucker DJ: Biologic actions and therapeutic potential of the proglucagon-derived peptides. Nat Clin Pract Endocrinol Metab 2005; 1:22-31.

67 Buffa R, Polak JM, Pearse AG, Solcia E, Grimelius L, Capella C: Identification of the intestinal cell storing gastric inhibitory peptide. Histochemistry 1975;43:249-255.

68 Sjöström L, Narbro K, Sjöström CD, Karason K, Larsson B, Wedel H, Lystig T, Sullivan M, Bouchard C, Carlsson B, Bengtsson C, Dahlgren S, Gummesson A, Jacobson P, Karlsson J, Lindroos AK, Lönroth H, Näslund I, Olbers T, Stenlof K, Torgerson J, Agren G, Carlsson LM: Effects of bariatric surgery on mortality in Swedish obese subjects. N Engl J Med 2007; 357:741-752.

69 Nauck MA, Baller B, Meier JJ: Gastric inhibitory polypeptide and glucagon-like peptide-1 in the pathogenesis of type 2 diabetes. Diabetes 2004;53(suppl 3):S190-S196.

70 Miyawaki K, Yamada Y, Ban N, Ihara Y, Tsukiyama K, Zhou H, Fujimoto S, Oku A, Tsuda K, Toyokuni S, Hiai H, Mizunoya W, Fushiki T, Holst JJ, Makino M, Tashita A, Kobara Y, Tsubamoto Y, Jinnouchi T, Jomori T, Seino Y: Inhibition of gastric inhibitory polypeptide signaling prevents obesity. Nat Med 2002;8: 738-742.

71 Cho YM, Kieffer TJ: K-cells and glucose-dependent insulinotropic polypeptide in health and disease. Vitam Horm 2010;84:111-150.

72 Creutzfeldt W, Ebert R, Willms B, Frerichs H, Brown JC: Gastric inhibitory polypeptide (GIP) and insulin in obesity: increased response to stimulation and defective feedback control of serum levels. Diabetologia 1978; 14: 15-24.

73 Salera M, Giacomoni P, Pironi L, Cornia G, Capelli M, Marini A, Benfenati F, Miglioli M, Barbara L: Gastric inhibitory polypeptide release after oral glucose: relationship to glucose intolerance, diabetes mellitus, and obesity. J Clin Endocrinol Metab 1982;55:329-336.

74 Getty-Kaushik L, Song DH, Boylan MO, Corkey BE, Wolfe MM: Glucose-dependent insulinotropic polypeptide modulates adipocyte lipolysis and reesterification. Obesity (Silver Spring) 2006;14:1124-1131.

75 Oben J, Morgan L, Fletcher J, Marks V: Effect of the entero-pancreatic hormones, gastric inhibitory polypeptide and glucagon-like polypeptide-1(7-36) amide, on fatty acid synthesis in explants of rat adipose tissue. J Endocrinol 1991;130:267-272.

76 McClean PL, Irwin N, Cassidy RS, Holst JJ, Gault VA, Flatt PR: GIP receptor antagonism reverses obesity, insulin resistance, and associated metabolic disturbances induced in mice by prolonged consumption of high-fat diet. Am J Physiol Endocrinol Metab 2007; 293:E1746-E1755.
77 Wice BM, Reeds DN, Tran HD, Crimmins DL, Patterson BW, Dunai J, Wallendorf MJ, Ladenson JH, Villareal DT, Polonsky KS: Xenin-25 amplifies GIP-mediated insulin secretion in humans with normal and impaired glucose tolerance but not type 2 diabetes. Diabetes 2012;61:1793-1800.

-78 Feurle GE, Klein A, Hamscher G, Metzger JW, Schuurkes JA: Neurokinetic and myokinetic effects of the peptide xenin on the motility of the small and large intestine of guinea pig. J Pharmacol Exp Ther 1996;278:654-661.

79 Leckstrom A, Kim ER, Wong D, Mizuno TM: Xenin, a gastrointestinal peptide, regulates feeding independent of the melanocortin signaling pathway. Diabetes 2009;58:87-94.

80 Mustain WC, Rychahou PG, Evers BM: The role of neurotensin in physiologic and pathologic processes. Curr Opin Endocrinol Diabetes Obes 2011;18:75-82.

81 Evers BM: Neurotensin and growth of normal and neoplastic tissues. Peptides 2006;27: 2424-2433.

82 Kim ER, Mizuno TM: Role of neurotensin receptor 1 in the regulation of food intake by neuromedins and neuromedin-related peptides. Neurosci Lett 2010;468:64-67.

83 Low MJ: Clinical endocrinology and metabolism. The somatostatin neuroendocrine system: physiology and clinical relevance in gastrointestinal and pancreatic disorders. Best Pract Res Clin Endocrinol Metab 2004; 18: 607-622.

84 Lam DD, Przydzial MJ, Ridley SH, Yeo GS, Rochford JJ, O’Rahilly S, Heisler LK: Serotonin $5-\mathrm{HT}_{2 \mathrm{C}}$ receptor agonist promotes hypophagia via downstream activation of melanocortin 4 receptors. Endocrinology 2008; 149:1323-1328.

85 Smith SR, Prosser WA, Donahue DJ, Morgan ME, Anderson CM, Shanahan WR: Lorcaserin (APD356), a selective 5-HT(2C) agonist, reduces body weight in obese men and women. Obesity (Silver Spring) 2009;17:494-503.

86 Fidler MC, Sanchez M, Raether B, Weissman NJ, Smith SR, Shanahan WR, Anderson CM; Group BCT: A one-year randomized trial of lorcaserin for weight loss in obese and overweight adults: the BLOSSOM trial. J Clin Endocrinol Metab 2011;96:3067-3077.

87 Cheng CY, Chu JY, Chow BK: Central and peripheral administration of secretin inhibits food intake in mice through the activation of the melanocortin system. Neuropsychopharmacology 2011;36:459-471.

88 Moran-Ramos S, Tovar AR, Torres N: Diet: friend or foe of enteroendocrine cells - how it interacts with enteroendocrine cells. Adv Nutr 2012;3:8-20.

89 Engelstoft MS, Egerod KL, Holst B, Schwartz TW: A gut feeling for obesity: 7TM sensors on enteroendocrine cells. Cell Metab 2008;8: 447-449. 